\title{
PENGAWASAN PEMERINTAH DAERAH DALAM PENANGGULANGAN TERORISME DI KOTA CIMAHI
}

\author{
Endang Priatna1), Titin Rohayati2), Tinda Irawaty ${ }^{3}$ \\ 1), 2), 3)Prodi Ilmu Pemerintahan, Fakultas Ilmu Sosial dan Ilmu Politik, \\ Universitas Jenderal Achmad Yani Cimahi - Bandung
}

\begin{abstract}
Abstrak
Pada tahun 2013, 2018, dan 2019 terjadi penangkapan terorisme di Kota Cimahi. Kota Cimahi dianggap rawan menjadi tempat persembunyian teroris. Maka penelitian ini bertujuan untuk mengetahui pengawasan Pemerintah Daerah Kota Cimahi dalam penanggulangan terorisme. Metode penelitian yang digunakan yaitu desktiptif dengan pendekatan kualitatif. Hasil penelitian menunjukkan bahwa Pemerintah DaerahKota Cimahi dalam penanggulangan terorisme, melalui Kantor Kesatuan Bangsa dan Politik (Kesbangpol) Kota Cimahi bersinergi dengan pihak kepolisian dan juga masyarakat Kota Cimahi. Melalui Forum Kewaspadaan Dini Masyarakat, Kesbangpol bersama dengan pihak kepolisian, memberi edukasi kepada masyarakat terkait radikaslime dan terorisme. Baik pihak Kesbapol dan kepolisian, telah memiliki SDM yang berkompeten dalam pengawasan. Hanya saja sejauh ini yang menjadi kekurangan adalah terkait kuantitas dari SDM di kepolisian. Perencanaan pengawasan dalam penanggulangan terorisme di Kota Cimahi dilakukan dengan pemetaan tugas kepada masing-masing unit yang ada di kepolisian. Anggaran khusus untuk penanganan terorisme belum ada. Jadi, kesimpulannya adalah pengawasan penanggulangan di Pemerintah Kota Cimahi dilakukan dengan cara mengajak masyarakat untuk melihat lingkungan sekitarnya, dan apabila ada hal yang mencurigakan bisa langsung melaporkan kepada Pemerintah atau pihak kepolisian.
\end{abstract}

\section{Kata Kunci: Pengawasan, Terorisme, Pemerintah Daerah}

\begin{abstract}
In 2013, 2018, and 2019, there were arrests of terrorism in Cimahi City. Cimahi City is considered prone to become a hiding place. So this research seeks to study the supervision of the City Government of Cimahi in combating terrorism. The results showed that the City of Cimahi in combating terrorism, National Unity, and Politics in Cimahi City synergized with the police and also the people of Cimahi City. Through the Community Early Awareness Forum, Kesbangpol together with the police, provide education to the public regarding radikaslime and terrorism. Both the Kesbapol and the police have competent human resources in supervision. It's just beyond this that the shortcomings are related to the strengths of $H R$ in the police. Planning of supervision in combating terrorism in Cimahi City is carried out by monitoring the tasks of each unit in the police. A special budget for handling terrorism does not yet exist. So, the conclusion is that the monitoring of countermeasures in the Cimahi City Government is carried out by inviting the public
\end{abstract}


to look at the adjacent environment, and denies that what can be done can be directly reported to the Government or the police.

\section{Keywords: Monitoring, Terrorism, Local Government}

\section{PENDAHULUAN}

Aksi terorisme sebagai salah satu dari kejahatan luar biasa atau extra ordinary crime memerlukan penanggulangan menggunakan sistem yang luar biasa pula, karena disebabkan oleh beberapa hal yaitu diantaranya. Adanya maksimalisasi korban, target sasaran aksi terorisme bersifat acak (random), dan adanya kemungkinan untuk menggunakan senjata pemusnah massal, serta dapat membahayakan perdamaian baik dalam negeri maupun internasional.

Ancaman aksi terorisme tentu sangat berpengaruh terhadap kehidupan dan stabilitas sosial di masyarakat, terorisme saat ini berbeda dengan masa lalu dan tentu ancamannya juga lebih besar. Terorisme kini hadir dengan berbagai gaya baru, bahkan terorisme ini secara organisasi sangat terorganisir dengan baik sehingga memiliki sistem yang rapih dalam melakukan aksi teror di lapangan. Salah satu cara yang dilakukan para teroris ini yaitu berbaur dengan lingkungan, sehingga tidak mudah terdeteksi oleh aparat keamanan. Menggunakan pakaian yang tidak mencolok dan berbaur dengan masyarakat luas.

Kota Cimahi sebagai salah satu daerah yang terindikasi rawan sebagai persembunyian teroris, tentu sudah selayaknya berperan aktif dalam pengawasan terorisme, terutama dalam melakukan pencegahan. Saat ini penanggulangan terorisme yang dilakukan oleh Pemerintah Daerah masih kurang optimal, karena sudah berulang kali terjadi penangkapan teroris di wilayah Kota Cimahi. Peristiwa penangkapan kasus yang terindikasi sebagai anggota teroris di Kota Cimahi diawali pada 10 Mei 2013 yang berhasil ditangkap di salah satu ruko daerah Melong Kecamatan Cimahi Selatan. 
Pada bulan Juni 2018, juga terjadi lagi penangkapan terduga teroris di wilayah Polres Kota Cimahi. Kemudian penangkapan terjadi pada bulan April 2019 yang menyebabkan empat orang anggota polisi mengalami luka tusukan senjata tajam, serta penangkapan yang terakhir yaitu adanya terduga teroris pada bulan September 2019 di salah satu rumah kost yang diduga sebagai tempat untuk merakit alat peledak. Pelaku terindikasi teroris memiliki keseharian yang tertutup dengan masyarakat dan berjualan sebagai pedagang cireng. Densus 88 berhasil mengungkap aksi terorisme ini dengan mengamankan laptop dan alat merakit bom.

Selain adanya peristiwa terorisme, kelompok-kelompok yang terindikasi radikal juga banyak dijumpai di Kota Cimahi. Kelompokkelompok yang anti dengan Pancasila. Banyaknya kos-kosan dan kontrakan di daerah Kota Cimahi, sebagai peluang untuk para terorisme bersembunyi.

Dari adanya peristiwa penangkapan terorisme yang berulang kali di Kota Cimahi, Pemerintah Daerah seharusnya lebih memperketat pengawasan terorisme dan radikalisme. Dengan adanya Undang-Undang No 5 Tahun 2018 tentang Penanggulangan Terorisme, bisa menjadi acuan bagi Pemerintah Kota Cimahi untuk bergerak menghilangkan terorisme dan radikalisme.

Hasil temuan awal dari penelitian ini, tidak ada program khusus yang dilakukan Pemerintah Kota Cimahi untuk penaggulangan terorisme. Melalui Kesbangpol, pengawasan yang dilakukan bersifat umum mengenai masalah-masalah yang terjadi di masyarakat. Tidak ada perencanaan khusus untuk melakukan pengawasan terorisme, akan tetapi sumber daya manusia sudah dipersiapkan dengan cukup baik dan memiliki kompetensi yang sesuai dengan permasalahan yang dihadapi.

Pengawasan pada dasarnya merupakan suatu tindakan atau kegiatan dalam berbagai aktivitas lembaga organisasi terhadap pelaksanaan program, baik dalam organisasi publik maupun privat. Oleh karena itu, sangat dibutuhkan kegiatan pengawasan supaya meningkatkan 
efisiensi dan profesional pelaksanaan kelembagaan.

Optimalisasi pelaksanan pengawasan pemerintah menurut (Makmur:2015) memerlukan beberapa variable penunjang, yaitu perencanaan program pengawasan, sumber daya manusia yang memadai, standar pengawasan, mekanisme pengawasan, dan lainnya. Sasaran atau ruang lingkup dari pengawasan mencakup diantaranya, yaitu, aktivitas pemerintah, produk pemerintahan, sumber-sumber pemerintahan, mekanisme kerja pemerintahan, dan kebijakan-kebijakan pemerintahan.

Menurut Siagian dalam (Makmur:2015) mengatakan bahwa pengawasan merupakan proses pengamatan dari pelaksanaan seluruh kegiatan organisasi untuk menjamin agar supaya pekerjaan yang sedang dilakukan berjalan sesuai dengan rencana yang telah ditentukan sebelumnya.

Untuk itu, baik Pemerintah Pusat maupun Pemerintah Daerah, memiliki peran yang penting dalam pengawasan penanggulangan aksi radikalisme dan terorisme. Pemerintah Pusat dan Daerah, harus mejalankan amanat dari Undang-Undang Dasar 1945, yaitu melindungi segenap bangsa Indonesia dan seluruh tumpah darah Indonesia. Pemerintah wajib dan harus melindungi semua lapisan warga negaranya.

Pemerintah telah membentuk badan khusus untuk manangani aksi terorisme yaitu Bandan Nasional Penanggulangan Terorisme (BNPT), badan ini dibentuk berdasarkan Peraturan Presiden Nomor 12 Tahun 2012 tentang BNPT. BNPT juga merupakan elaborasi dari Undang-Undang Nomor 34 Tahun 2004 tentang TNI dan Undang-Undang Nomor 2 Tahun 2002 tentang POLRI.

Pengawasan pelaksanaan Pemerintah Daerah Kota Cimahi belum dilakukan secara maksimal sehingga berdampak kepada koordinasi yang dilakukan dengan lembaga terkait seperti Badan Nasional Penanggulangan Terorisme, Polres dan lembaga lainnya. Dalam beberapa tahun terakhir terjadi penangkapan terindikasi teroris yang terjadi di Cijerah dan Cibeber. Kerjasama dan koordinasi dengan lembaga lembaga untuk penanggulangan terorisme penting dilakukan guna memudahkan atau meringankan dalam melakukan pengawasan penanggulangan terorisme. 
Pengawasan penanggulangan radikalime dan terorisme sangat penting untuk dilakukan di Kota Cimahi. Aksi terorisme yang tidak dapat terperediksi menuntut Pemerintah Kota Cimahi, harus lebih pro aktif. Pemerintah Kota Cimahi, tidak boleh lengah dalam penanggulangan radikalime dan terorisme. Pengawasan terorisme tidak hanya berbicara mengenai penindakan dengan penegak hukum, akan tetapi yang lebih penting adalah melalukan pencegahan. 


\section{METODE PENELITIAN}

Penelitian ini menggunakan deskriptif dengan pendekatan kualitatif. Menurut (Sugiyono:2012) mengatakan bahwa penelitian kualitatif adalah metode penelitian yang melandaskan pada filsafat post-positivisme, yang digunakan pada objek yang alamiah di mana peneliti adalah instrumen kunci. Senada dengan yang disampaikan oleh (Moleong:2011) bahwa penelitian kualitatif adalah penelitian yang bermaksud memahami fenomena tentang apa yang dialami oleh subjek penelitian, misalnya perilaku, persepsi, motivasi, dan lainnya.

Adapun untuk unit analisis dari penelitian ini yaitu Kantor Kesatuan Bangsa dan Politik (Kesbangpol) Kota Cimahi, Polisi Resort (Polrest) Kota Cimahi, Badan Nasional Penanggulangan Terorisme, Ketua RT/02 RW/01 Kelurahan Cibeber. Teknik pengumpulan data dilakukan dengan cara studi pustaka, observasi, wawancara, dan dokumentasi. Lokasi penelitian yaitu di Pemerintah Kota Cimahi, Provinsi Jawa Barat.

\section{PEMBAHASAN}

Pentingnya tindakan pencegahan pergerakan terorisme tentunya bukan hanya sebagai tanggung jawab para aparat penegak hukum semata, setiap lembaga pemerintah tidak terkecuali pemerintah daerah memiliki peran tersendiri dalam pencegahan terorisme. Hal tersebut disebabkan karena banyaknya aksi-aksi atau tindakan yang terindikasi sebagai gerakan-gerakan terorisme terjadi di daerah. Oleh karena itu, perlu peningkatkan pengawasan oleh setiap pemerintah daerah untuk dapat mencegah aksis teror dan paham radikal masuk ke dalam daerah tersebut.

Pengawasan dilakukan tentu untuk mencegah paham radikal tumbuh dan berkembang, serta dapat menciptakan situasi dan kondisi yang aman dan kondusif bagi masyarakat. Dalam beberapa tahun terakhir terjadi penangkapan yang terindikasi sebagai kelompok terorisme di wilayah Kota Cimahi. Kejadian terakhir, terjadi pada 29 September 2019 di salah satu rumah kost. Terjadinya penangkapan tersebut menandakan bahwa pengawasan terorisme harus semakin ditingkatkan sebagai tindakan kewaspadaan nasional. Dalam pengawasan, beberapa hal 
yang menjadi perhatian yaitu diukur dari, sumber daya manusia, perencanaan, anggaran/finansial, standar pengawasan dan mekanisme pengawasan.

\section{A. Sumber Daya Manusia}

Sumber daya manusia harus memenuhi persyaratan teknis pekerjaan yang telah ditetapkan oleh struktur organisasi. setiap pegawai harus mempunyai intelektual dan kemampuan untuk melaksanakan tugas yang menjadi tanggung jawabnya. Kaitannya dengan pengawasan terorisme, sumber daya manusia yang dimiliki oleh Pemerintah Kota Cimahi tentunya diberikan pelatihan-pelatihan intelijen dan memiliki kompetensi yang cukup.

Pernyataan di atas, sesuai dengan pendapat yang disampaikan oleh Bapak Agus selaku Pengelola Pemantauan Kantor Kesatuan Bangsa dan Politik (Kesbangpol) Kota Cimahi mengatakah bahwa:

"Dari Kesbangpol sebagai bagian dari pemerintahan khususnya hanya melakukan deteksi dini, karena hal ini sangat sensitif, kesbangpol secara teknis juga bekerja sama dengan aparat penegak hukum seperti kepolisisan dan TNI, Sumberdaya manusia yang disiapkan tentunya diberi pendidikan intelijen, apabila ada yang mencurigakan dilakukan pencegahan lebih awal."

Berdasarkan pendapat informan di atas, menunjukkan bahwa tugas dari Pemerintah Kota Cimahi lebih menekankan kepada pencegahan karena secara teknis di lapangan Pemerintah Kota Cimahi bekerja sama dengan aparat penegak hukum yaitu kepolisian dan pihak TNI. Pemerintah Kota Cimahi tidak bekerja sendiri dalam melakukan pengawasan terkait dengan penanggulangan radikalisme dan terosisme di wilayah Kota Cimahi.

Dengan melibatkan pihak kepolisan dan TNI, secara sumber daya manusia, Pemerintah Kota Cimahi melibatkan orang-orang yang memang kompeten di bidang tersebut. Pendapat lain dari perwakilan Intelijen Polisi Resort Cimahi, Bapak Suryo Supriyo, yang mengatakan bahwa: 
"secara kompetensi, sumber daya manusia yang dimiliki tentunya sudah cukup baik. Akan tetapi, dari segi kuantitas masih kurang."

Walaupun secara kualitas sumber daya manusia yang dimiliki kepolisian sudah memadai, apabila jumlah sumber daya manusia belum mencukupi maka tentu ini mempengaruhi terhadap pengawasan radikalisme dan terorisme. Dengan jumlah yang belum mencukupi akan menghambat pelaksanaan pengawasan, dan berujung kepada ketidakefektifan pengawasan yang dilakukan oleh Pemerintah Kota Cimahi dengan kepolisian.

Selain melakukan wawancara dengan berbagai informan, penulis juga melakukan observasi langsung di lapangan terkait dengan faktor sumber daya manusia. Dari hasil observasi menunjukkan bahwa sumber daya manusia yang dimiliki oleh Kesbangpol Kota Cimahi dan Polres Kota Cimahi untuk melakukan pengawasan radikalisme dan terorisme sudah memiliki kompetensi yang sesuai, baik secara wawasan kebangsaan maupun terkait dengan radikalisme dan terorisme. Jadi, memang pihak kepolisian, masih kekurangan personil atau sumber daya manusia, untuk pengawasan terorisme.

Selain berkerja sama dengan pihak kepolisian, upaya lain dalam pengawasan yang dilakukan Pemerintah Kota Cimahi, yaitu dengan membentuk forum. Forum tersebut bernamakan yaitu Forum Kewaspaadan Dini Masyarakat. Tujuan diadakannnya forum ini untuk melibatkan langsung masyarakat dalam pengawasan radikalisme dan terorisme. Apabila masyarakat Kota Cimahi mencurigain seseorang atau sekelompok orang yang mengarah kepada radikalisme dan terorisme, bisa memberikan laporan kepada Kesbangpol atau aparat penegak hukum. Masyarakat diberikan pemahaman tentang bagaimana bahaya dari radikalisme dan terorisme apabila masuk dalam lingkungan masyarakat atau bahkan terjerumus ke dalam kelompok-kelompok radikal.

Sumber daya manusia diharuskan untuk dapat memenuhi tuntutan dan persyaratan dalam suatu organisasi, maka semua tenaga fisik, 
intelektual serta sikap mental harus sesuai dengan yang diperlukan dalam melaksanakan suatu pengawasan, dan dilaksanakan dengan sebaikbaiknya. Kualitas SDM yang berkompeten, sangat diperlukan dalam kegiatan pengawasan, karena pengawasan itu ibarat mata dan telinga untuk dapat melihat fakta yang ada di kemudian dijadikan bahan untuk menentukan kebijaksanaan dan tindakan korektif yang akan diambil.

Sumber daya manusia yang dibutuhkan memiliki kemampuan atau kompetensi yang baik tentunya adalah mengetahui bagaimana ciri-ciri dari kelompok-kelompok atau individu yang dianggap terpapar paham radikal. Karena permasalahan radikalisme dan terorisme bukan dilihat dari segi ciri fisik atapun sikap atau bahkan pakaian yang dikenakan.

Pemahaman radikalisme dan terorisme terletak di dalam pikiran (mind) individu atau kelompok-kelompok radikal terorisme. Sehingga kompetensi sumber daya manusia terutama dalam pengawasan terorisme bukan hanya memiliki pemahaman di bidang pengawasan akan tetapi harus memahami ciri-ciri dari paham-paham radikal yang diindikasikan terdapat di lingkungan masyarakat.

Karena permasalahan radikalisme dan terorisme yang sangat sensitif, maka para petugas pengawasan baik dari Pemerintah Daerah Kota Cimahi yang bersinergi dengan aparat penegak hukum dalam hal ini adalah Polrest Kota Cimahi tidak boleh salah dalam melakukan pengawasan radikalisme dan terorisme, sehingga pengawasan dapat berjalan dengan baik dan tidak menyudutkan salah satu kelompok dalam masyarakat yang diakibatkan oleh ketidakpahaman sumber daya manusia yang dimiliki melakukan pengawasan.

Pemerintah Kota Cimahi memiliki kompetensi yang cukup dan dapat memahami untuk melakukan deteksi dini apabila terjadi hal-hal yang mencurigakan di lingkungan sekitar masyarakat. Selain itu, Pemerintah Kota Cimahi memberdayakan masyarakat untuk menciptakan kondisi lingkungan yang kondusif.

B. Perencanaan

Perencanaan merupakan tahapan yang paling awal dalam penentuan 
sebuah program atau kegiatan dalam suatu oraganisasi. Dalam tahapan ini berbagai tujuan dan strategi untuk pencapaian tujuan ditetapkan secara menyeluruh guna mengintegrasikan dan mengkoordinasikan setiap pekerjaan organisasi, maka secara umum perencanaan dapat dikatakan sebagai suatu proses gambaran tentang apa-apa saja yang akan dilakukan. Mulai dari tujuan, strategi dan bagaimana sistem untuk mensinergikan antara seluruh elemen organisasi.

Perencanaan harus dilakukan se-detail mungkin sehingga tujuan dari pengawasan radikalisme dan terorisme dapat berjalan dan tercapai sesuai dengan apa yang ditetapkan. Dalam melakukan pengawasan radikalisme dan terorisme Pemerintah Kota Cimahi terkait dengan perencanaan, penulis telah melakukan wawancara dengan Bapak Agus dari Kesbangpol Kota Cimahi, beliau mengatakan bahwa:

"untuk pendeteksian kita berdasarkan informasi, laporanlaporan dan pendekteksian yang dilakukan oleh teman-teman dari kepolisian. Kesbangpol tidak bergerak sendiri. Jadi, pemerintah lebih fokus pada edukasi dan penyuluhan, supaya melakukan pencegahan."

Dari hasil wawancara dapat dipahami, bahwa Pemerintah Kota Cimahi dalam melakukan perencanaan pengawasan terorisme tidak memiliki perencanaan khusus, terkait bagaimana strategi dan sistem pengawasan yang akan dijalankan. Akan tetapi perencanaan yang dilakukan yaitu dengan melakukan edukasi dan penyeluhan supaya dapat mencegah lahirnya paham radikalime dan terorisme di masyarakat. Pendapat lainnya disampaikan oleh Bapak Supriyo, selaku Kanit 4 Intelkam, yang mengatakan bahwa:

"perencanaan yang dilakukan yaitu diantaranya: pertama, melakukan maping wilayah pendataan yang terindikasi terpapar radikalisme. Kedua, menyampaikan kepada anggoata, kemudian pembagian tugas kepada setiap unit. Ketiga, melakukan koordinasi dengan instansi terkait."

Dari hasil wawancara dengan Kanit 4 Intelkam tersebut, dapat dilihat bahwa perencanaan pengawasan radikalisme dan terorisme di Kota Cimahi dilakukan secara bertahap dan sistematis. Ketika dilakukan 
pemetaan wilayah, maka proses pengawasan dapat dilakukan secara komprehensif. Selain itu, adanya pembagian tugas antara divisi atau unitunit, mempermudah dalam melakukan pengawasan. Karena tupoksi atau tanggung jawab masing-masing unit sudah jelas.

Dengan adanya pembagian tugas, tentu mempermudah para anggota unit untuk memahami peran dan fungsinya masing-masing, sehingga dapat mendukung untuk dapat tercapainya tujuan dari pengawasan radikalisme dan terorisme. Pendeteksian atau deteksi dini paham radikalisme dan terorisme tentunya tidak mudah untuk dilakukan, maknanya perencanaan yang dilakukan harus dapat menjamin tercapainya sasaran atau tujuan melaului strategi-strategi yang diputuskan dalam perencaan pengawasan radikalisme dan terorisme. Kepolisian juga melengkapi perencanaan dan dokumen pelaksanaan pengawasan.

\section{Anggaran}

Selain sumber daya manusia dan perencaan, yang harus dipersiapkan sebelum melakukan pengawasan adalah unsur material atau anggaran. Anggaran memiliki peranan yang cukup penting untuk dapat menunjang segala aktivitas pengawasan baik sarana maupun prasarana. Bapak Agus, perwakilan Kesbangpol Kota Cimahi mengatakan bahwa:

"kita lebih jauh kepada pembinaan ormas. Radikalisme dan terorisme ujungnya adalah kondusifitas daerah. Keadaan lingkungan yang aman dan tertib. Jadi, tidak ada anggaran khusus untuk itu (pengawasan terorisme)."

Hal ini juga dibenarkan oleh Bapak Suryo Supriyo, Kanit 4 Intelkam, bahwa untuk pengawasan radikalisme dan terorisme di wilayah Kota Cimahi, belum ada bantuan anggaran maupun sarana dan prasarana untuk menunjang pelaksanaan pengawasan.

Tidak adanya anggaran khusus, karena sejauh ini di wilayah Kota Cimahi dalam pengawasan selama ini dilakukan dengan melakukan 
pendekatan kepada masyarakat, memberikan edukasi kepada ormas dan masyarakat luas. Kesbangpol mengeluarkan anggaran untuk pembinaan ormas. Tujuannya untuk meningkatkan kewaspadaan, dan masyarakat lebi sadar dan peduli terhadap lingkungan sekitarnya.

Pengawasan pendahuluan yang dilakukan Pemerintah Kota Cimahi dalam penanggulangan terorisme, pada dasarnya pengawasan pendahuluan yang proses persiapan dan perumusan terkait apa-apa saja yang akan dilakukan. Pengawasan pendahuluan memuat tentang bagaimana strategi dan sistem yang akan dilaksanakan dalam pengawasan. Pemerintah Kota Cimahi bersama kepolisian dalam pelaksaan pendahuluan dapat dikatakan masih cukup baik. Pengawasan terorisme membutuhkan waktu yang sangat lama, sehingga memerlukan perencanaan yang matang, agar dapat melakukan pendeksian yang sangat tepat.

Selain itu Pemerintah Daerah Kota Cimahi melalui Kesbangpol bersama dengan kepolisian telah didukung oleh sumber daya manusia yang memiliki kompetensi dalam pengawasan radikalisme dan terorisme. Kompetensi sumber daya manusia sangat dibutuhkan untuk dapat menunjang kelancaran dalam mendeteksi keberadaan kelompokkelompok simpatisan teroris.

D. Standar Pengawasan

Dalam proses pengawasan, perlu ada standar dalam pelaksanaannya. Standar pengawasan ini menjadi salah satu tolak ukur untuk menciptakan pengawasan yang efektif dan efisien. Suatu pengawasan yang baik dapat dilihat dari sejauh mana pengawasan yang telah dilaksanakan dibandingkan dengan standar yang ada. Suatu pengawasan yang dikatakan baik, apabila telah memenuhi atau setidaknya mendekati standar atau ketentuan yang berlaku. Dari hasil 
wawancara dengan pihak Kantor Kesatuan Bangsa dan Politik Kota Cimahi, Bapk Agus mengatakan bahwa:

"Belum ada standar pengawas yang komprehensif. Akan tetapi standar yang paling minimal dengan deteksi dini untuk mencegah. Tiap ada kesempatan mengobrol dengan tokoh masyarakat tentang kondusifitas dan keamanan daera, maka standar pengawasan terorisme, termasuk dalam hal tersebut."

Standar pengawasan khusus yang diterapkan oleh Pemerintah Kota Cimahi sejauh ini belum ada, jika dilihat dari hasil wawancara di atas. Standar pengawasan atau bisa juga disebutkan sebagai parameter yaitu adanya rencana strategis, adanya peraturan daerah dan dokumen pelaksanaan. Namun sejauh ini Pemda Kota Cimahi hanya melakukan koordinasi dengan pihak TNI, Polisi, tokoh masyarakat, ormas dan tokoh agama.

Dari hasil di lapangan, menujukkan bahwa Pemda Kota Cimahi belum memiliki rencana strategi. Jika dilihat dari bahanya radikalisme dan terorisme, dan juga dilihat kejadi terorisme yang berulang di Kota Cimahi, seharusnya Pemda Kota Cimahi dengan aparat kepolisian telah membuat standar pengawasan terhadap gerakan ini. Kelengahan dari lingkungan memunculkan peristiwa yang sama di Kota Cimahi. Karena Kota Cimahi bukan pertama kali ada kejadian terorisme.

Penjagaan ketat dari pihak kepolisian dirasa sangat diperlukan. Apalagi mengingat bahwa Kota Cimahi bukanlah wilayah yang cukup luas. Bahkan ada beberapa perguruan tinggi berada di wilayah Kota Cimahi, yang tentunya banyak orang perantau yang masuk ke wilayah ini.

Menurut Bapak Supriyo selaku Kanit 4 Intelkam bahwa pengawasan dilakukan secara melekat, yaitu pengawasan dilakukan secara sistemik. Pengawasan ini merupakan pengasawan yang paling intensif karena jarak antara subjek dan objek pengawasan sangat dekat. Pengawasan melekat identik dengan pengecekan, pemeriksaan, penelusuran, pelacakan dan lainnya. 
Standar pengawasan yang dilakukan melalui Forum Kewaspadaan Dini Masyarakat serta pengawasan secara melekat, sudah baik. Dokumen pelaksanaan pengawasan menjadi rahasia oleh pihak kepolisian. Namun jika dilihat dari hasil wawancara dan observasi, bahwa secara jelas belum ada standar pengawan yang dipunyai oleh Pemda Kota Cimahi. Tujuan dari standar pengawasan sendiri adalah untuk mengukur sejauh mana pengawasan radikalisme dan terorisme di wilayah Kota Cimahi.

E. Mekanisme Pengawasan

Mekanisme pengawasan merupakan suatu proses untuk menciptakan kegiatan dapat berjalan sesuai dengan perencanaan dan terhindar dari berbagai kesalahan-kesalahan yang mendasar. Oleh sebab itu perlu adanya mekanisme untuk dapat menciptakan pengawasan yang tepat dan senantiasa sejalan dengan ketentuan, agar tujuan dapat tercapai secara efektif dan efisien.

Mekanime yang dilakukan Pemerintah Kota Cimahi selain melakukan penyuluhan edukasi, dan membentuk forum masyarakat, Pemda bersama pihak kepolisian bekerja sama dengan tokoh agama, tokoh masyarakat, ormas yang ada di wilayah Kota Cimahi. Hasil wawancara dengan Kanit 4 Intelkam sejalan dengan yang disampaikan oleh Kapolres Cimahi AKBP Rusdy Pramana dalam berita online RRI yang mengatakan bahwa:

"kami melakukan silaturahmi Kamtibmas ke pondok-pondok pesantren, guna mencegah masuknya paham-paham radikalisme, jangan sampai pondok pesantren yang ada di wilayahnya menjadi tidak kondusif. Dari para tokoh pesantrem kami juga bisa mendapat masukan yang berguna bagi institusi kepolisian." (https://rri.co.id/daerah/729343/cimahi-rawan-tempatpersembunyian-teroris)

Jadi, Pemda Kota Cimahi bersama dengan TNI dan Polres Cimahi melakukan kegiatan pre emtyp, yaitu dengan cara memberikan penyuluhan kepada masyarakat luas dan tokoh-tokoh agama, serta membuat penjagaan ketat terhadap markas dan pos kepolisian. 
Pemda Kota Cimahi dalam melakukan pengawasan radikalisme dan terorisme, lebih menggunakan mekanisme dan pendekatan secara halus (soft approach). Hal ini untuk menambah wawasan masyarakat luas terkait dengan bahaya terorisme dan radikalisme. Karena masyarakat sendiri yang lebih mengetahui lingkungan sekitarnya, maka seluruh lapisan masyarakat harus turut berperan menjaga lingkungan yang aman, nyaman dan tertib.

Salah satu faktor yang dapat menyebabkan seseorang atau kelompok terjerumus dalam paham radikalisme dan terorisme yaitu masyarakat yang tidak dapat menyaring informasi yang salah. Belajar ilmu agama, akan tetapi tidak sadari bahwa telah terjerumus ke dalam lingkaran hitam. Sering sekali bahwa ajakan atau seruan pada kelompok teroris dilatar belakangi oleh agama. Salah satu propaganda yang digunakan adalah dengan menanamkan pemahaman takhfiri atau thagut. Paham takhfiri adalah mengkafirkan orang yang bukan beragama Islam. Bahkan yang beragama Islam pun dikafirkan apabila tidak sejalan atau menganut Islam sesuai dengan pemahamanya. Oleh karena itu pembentukan Forum Kewaspadaan Dini Masyarakat merupakan salah satu langkah yang positif untuk dapat mencegah paham radikalisme dan terorisme tumbuh di wilayah Kota Cimahi.

Pada 29 September tahun 2019, terjadi penangkapan yang terindikasi sebagai kelompok teroris di salah satu rumah kost yang terletak di Kelurahan Cibeber RT 02/RW 01, hal tersebut menjadi salah satu yang perlu dipertanyakan mengenai mekanisme yang telah dilakukan oleh pemerintah daerah dan aparat kepolisian, Polrest Kota Cimahi.

Selain pemerintah daerah dan aparat kepolisian, peran Rukun Warga dan Rukun Tetangga dalam pengawasan radikalisme dan terorisme memiliki peranan yang sangat penting, karena Rukun Tetangga dan Rukun Warga merupakan elemen yang berhubungan secara langsung dengan masyarakat. Seperti yang dikatakan oleh Rukun Tetangga (RT) 02 RW 01 Kelurahan Cibeber, Kecamatan Cimahi Selatan, Bapak Abdul Hadi 
mengatakan bahwa:

"semua warga terutama yang pendatang, harus melaporkan diri dengan membawa data diri seperti KK, KTP. Untuk mahasiswa harus membawa KTM. Dan kejadian penangkapan teroris yang terjadi pada 29 September 2019, dikarenakan tersangka tidak melaporkan diri dan tidak memberikan identitasnya sampai kejadian penangkapan tersebut."

Berdasarkan hasil wawancara di atas, secara mekanisme pengawasan dari tingkat RT sesungguhnya sudah ditegakan, untuk masyarakat yang ada di wilayah Cimahi harus melaporkan diri dan memberikan identitas KTP, KK dan dokumen lainnya. Akan tetapi masih ada pendatang yang tidak lapor, seperti halnya yang terjadi dengan tersangka teroris pada bulan September 2019 lalu. Kejadian itu tentunya harus menambah waspada para RT yang ada di Kota Cimahi. Apabila ada pendatang yang tidak melapor secepatnya, pihak RT bisa langsung mendatangi pendatang tersebut. Untuk meminimalisir kejadian yang sama di waktu yang akan datang. Dengan kata lain, pihak RT yang menjemput bola kepada para pendatang.

\section{KESIMPULAN}

Berdasarkan hasil penelitian dan pembahasan mengenai pengawasan yang dilakukan Pemerintah Kota Cimahi dalam penanggulangan terorisme, penulis menarik kesimpulan yaitu:

1. Pemerintah Kota Cimahi dalam melakukan pengawasan terorisme bekerja sama dengan Polisi Resort Cimahi sebagai lembaga teknis pengawasan di lapangan.

2. Dalam tahap pengawasan pendahuluan, Pemerintah Kota Cimahi melakukan dengan cukup baik. Dilihat dari sumber daya manusia yang sudah memiliki kompetensi. Paham terkait paham radikalisme dan terorisme.

3. Pengawasan juga dilakukan oleh ormas serta RT dan RW yang ada di wilayah Kota Cimahi. 
4. Bentuk pengawasan lainnya yaitu dengan membentuk Forum Kewaspadaan Dini Masyarakat, yang mana melibatkan langsung masyarakat luas.

5. Perencanaan yang dilakukan dalam penanggulangi radikalisme dan terorisme yaitu dengan pemetaan wilayah dan pembagian tugas setiap unit yang ada di Kesbangpol dan Kepolisian.

6. Anggaran khusus untuk pengawasan tidak ada. Hanya saja masuk pada anggaran Kesbangpol terkait dengan penjagaan lingkungan masyarakat yang aman, nyaman dan tertib.

\section{DAFTAR PUSTAKA}

Golose, Petrus. R. 2009. Deradikalisasi Teorisme: Humanis, Soul Approach Dan Menyentuh Akar Rumput. Jakarta : Yayasan Penegembangan Kajian Ilmu Kepolisian

Makmur, 2015. Efektifitaas Kebijakan Kelembagaan Pengawasan. Bandung: Refika Aditama

Manullang, 2004. Manajemen Personalia. Jakarta: Bhineka

Molleong, 2012. Metode Penelitian Kualitatif. Bandung: Remaja Rodakarya

Sugiyono, 2012. Metode Penelitian Kualitatif, Kuantitatif, Dan R\&D. Bandung: Alfabeta

Wahid, A., 2011. Kejahatan Terorisme, Perspektif Agama, Ham Dan Hukum. Bandung: Refika Aditama.

Windiani, 2017. Peran Indonesia dalam Memerangi Terorisme. Jurnal Ilmu Sosial, Vol.1 
Jurnal Caraka Prabu Vol. 4 No. 1 Juni 2020 